\title{
MODEL PENGEMBANGAN SEKOLAH MUHAMMADIYAH BERKUALITAS MELALUI TRANSFORMASI KURIKULUM AIK (AL- ISLAM DAN KEMUHAMMADIYAHAN)
}

\author{
Abdullah Aly \\ Program Studi Pendidikan Agama Islam, Fakultas Agama Islam, \\ Universitas Muhammadiyah Surakarta \\ E-Mail: aa130@ums.ac.id
}

\begin{abstract}
This study aims to describe the development model of quality Muhammadiyah schools through the transformation of the Al-Islam and Kemuhammadiyahan curriculum. The research method used is descriptive qualitative with library research approach and field research, with document studies, observations and interviews as a method of data collection. The material object of this research is Muhammadiyah Junior High School (SMPM) 01 in Surakarta and Muhammadiyah Junior High School (SMPM) Plus in Klaten. The study produced two main conclusions. First, the efforts to develop quality of SMPM 01 in Surakarta and SMPM Plus in Klaten were carried out by means of AIK curriculum transformation. This method focuses on developing two standards, namely: content standards and process standards. In the context of content standards and process standards, both schools transform AIK curriculum by adding material on Islamic Religion that has been established by government regulations, and adding activities through strengthening AIK learning in the classroom, and increasing religious co-curricular and extra-curricular activities. Second, the AIK learning process has the potential to develop quality Muhammadiyah schools. Both schools use varied methods in developing classroom learning activities, and in religious co-curricular and extra-curricular activities. In this case, the teachers use learning methods in the form of: habituation, memorization, practice and repetition, question and answer, discussion, games, and practice.
\end{abstract}

Keywords: Quality Schools; Curriculum Transformation; Al-Islam and Kemuhammadiyahan; Content Standards; Process Standards.

Abstrak: Penelitian ini bertujuan untuk mendeskripsikan model pengembangan sekolah Muhammadiyah yang berkualitas melalui transformasi kurikulum Al-Islam dan Kemuhammadiyahan. Metode penelitian yang digunakan adalah deskriptif kualitatif dengan pendekatan penelitian kepustakaan dan penelitian lapangan, dengan studi dokumen, pengamatan dan wawancara sebagai metode pengumpulan data. Objek material dari penelitian ini adalah Sekolah Menengah Pertama Muhammadiyah (SMPM) 01 Surakarta dan Sekolah Menengah Pertama Muhammadiyah (SMPM) Plus Klaten. Dari penelitian ini dapat dihasilkan dua kesimpulan pokok. Pertama, upaya pengembangan sekolah Muhammadiyah berkualitas di SMPM 01 Surakarta dan SMPM Plus Klaten dilakukan dengan cara transformasi kurikulum AIK. Cara ini difokuskan pada pengembangan dua standar, yaitu: standar isi dan standar proses. Dalam konteks standar isi dan standar proses, kedua sekolah melakukan transformasi kurikulum AIK dengan cara menambah materi Pendidikan Agama Islam yang telah ditetapkan oleh peraturan pemerintah, dan menambah kegiatan melalui penguatan pembelajaran AIK di kelas, dan menambah kegiatan ko-kurikuler dan ekstra-kurikuler keagamaan. Kedua, proses pembelajaran AIK sangat potensial untuk mengembangkan sekolah Muhammadiyah 
berkualitas. Kedua sekolah menggunakan metode yang bervariasi dalam mengembangkan kegiatan pembelajaran di kelas, dan dalam kegiatan ko-kurikuler dan ekstra-kurikuler keagamaan. Dalam hal ini, para guru menggunakan metode pembelajaran berupa: pembiasaan, hafalan, latihan dan pengulangan, tanya jawab, diskusi, game, dan praktik.

Kata Kunci: Sekolah Berkualitas; Transformasi Kurikulum; Al-Islam dan Kemuhammadiyahan; Standar Isi; Standar Proses.

\section{PENDAHULUAN}

Sebagai organisasi sosial keagamaan di Indonesia, Muhammadiyah selama ini dikenal sebagai pengelola pendidikan yang sangat fenomenal di Indonesia, dari PAUD (Pendidikan Anak Usia Dini) dan TK ABA (Taman Kanak-kanak Aisyiyah Bustanul Athfal), pondok pesantren sampai dengan perguruan tinggi. Pada level nasional, Muhammadiyah memiliki ribuan sekolah dan ratusan perguruan tinggi yang tersebar di seluruh provinsi, kabupaten dan kota di Indonesia. Khusus untuk sekolah, madrasah dan pondok pesantren pada tingkat sekolah dasar dan menengah, Muhammadiyah mengelola sebanyak 5.264 sekolah/madrasah/ pondok pesantren. Secara rinci, data tahun 2015 menunjukkan bahwa jumlah Sekolah Dasar (SD) yang dikelola oleh Muhammadiyah sebanyak 1.064 sekolah, jumlah Sekolah Menengah Pertama (SMP) Muhammadiyah sebanyak 1.111 sekolah, jumlah Sekolah Menengah Atas (SMA) sebanyak 567 sekolah dan jumlah Sekolah Menengah Kejuruan (SMK) sebanyak 564 sekolah. Selanjutnya, Madrasah Ibtidaiyah (MI) yang dikelola oleh Muhammadiyah sebanyak 1.188 madrasah, jumlah Madrasah Tsanawiyah (MTs) 521 madrasah, jumlah Madrasah Aliyah (MA) sebanyak 178 madrasah, dan jumlah pondok pesantren Muhammadiyah sebanyak 89 pesantren. Data ini merujuk kepada Majlis Dikdasmen PPM Periode 2010-2015.

Dari data 5.264 di atas ada 1.488 sekolah, madrasah dan pondok pesantren yang dikelola oleh Majelis Dikdasmen Pimpinan Wilayah Muhammadiyah
Jawa Tengah. Secara rinci, data tahun 2016 menunjukkan bahwa SD yang dikelola oleh Muhammadiyah Jawa Tengah sebanyak 217 sekolah, jumlah SMP sebanyak 291 sekolah, jumlah SMA sebanyak 114 sekolah, jumlah SMK sebanyak 181 sekolah, dan jumlah SLB sebanyak 6 sekolah. Selanjutnya, MI yang dikelola oleh Muhammadiyah Jawa Tengah sebanyak 521 madrasah, jumlah MTs sebanyak 115 madrasah, jumlah MA sebanyak 18 madrasah, dan jumlah pondok pesantren sebanyak 25 pesantren. Data ini merujuk kepada Majlis Dikdasmen PWM Jawa Tengah Tahuns 2016.

Paparan data di atas oleh para peneliti baik peneliti luar negeri maupun peneliti Indonesia telah dicatat sebagai bukti empirik bahwa Muhammadiyah memiliki peran penting dalam pengembangan pendidikan Islam di Indonesia. Sebagai salah satu contoh adalah Elizabeth Fuller Collin dalam penelitiannya pada 2004 menyatakan bahwa Muhammadiyah berperan penting dalam pengembangan nilai-nilai demokrasi berbasis Islam di Indonesia (Collin, 2004: 93-120). Peneliti lain juga menegaskan bahwa peran Muhammadiyah dalam pengembangan pendidikan Islam di Indonesia tak terbantahkan lagi. Misalnya, Asna Husin dalam penelitiannya berkesimpulan bahwa pendidikan yang dikembangkan oleh Muhammadiyah mampu mengembangkan kesadaran pluralisme berbasis Islam di kalangan para peserta didik (Husin, 2009: 121141). Sementara itu, peneliti Indonesia memperkuat kesimpulan bahwa 
Muhammadiyah memiliki peran penting dalam pengembangan pendidikan di Indonesia. Dalam penelitiannya pada 2012, Nurwanto berkesimpulan bahwa Muhammadiyah telah berperan penting dalam menanamkan nilai-nilai keadilan gender lewat pembelajaran dan buku teks Al-Islam dan Kemuhammadiyahan (Nurwanto, 2012: 149-173). Lebih lanjut, Mohamad Ali dalam penelitiannya pada 2016 menghasilkan kesimpulan bahwa pendidikan Muhammadiyah dikembangkan dengan tujuan untuk mengarahkan perubahan sosial yang terjadi di masyarakat dan untuk berperan dalam pengembangan sains dan teknologi di Indonesia (Ali, 2016: 43-56).

Gambaran peran Muhammadiyah dalam pendidikan Islam di Indonesia di atas menunjukkan bahwa masih ada celah menarik yang perlu diteliti dari praktik pendidikan Muhammadiyah. Salah satunya adalah upaya pengembangan kualitas sekolah Muhammadiyah melalui transformasi kurikulum AIK. Arti penting dari upaya pengembangan sekolah Muhammadiyah tampaknya dilatarbelakangi oleh keinginan Muhammadiyah untuk melakukan penguatan peran Muhammadiyah dalam peningkatan kualitas pendidikan Islam di Indonesia. Gerakan ini menuntut upaya sistematis dari para pengelola sekolah Muhammadiyah dari berbagai level untuk mentransformasi kurikulumnya, terutama kurikulum AIK.

Berdasarkan temuan awal dapat ditegaskan bahwa sekolah-sekolah Muhammadiyah yang berkualitas ditandai keberanian manajemen yang memulai melakukan inovasi dan transformasi manajemen, kurikulum dan program pendidikan. Contoh sekolah yang masuk kategori initerutama pada tingkat SD/MI - adalahSD Muhammadiyah Program Khusus (PK) Kottabarat, SD Muhammadiyah Mutual Magelang, SD Muhammadiyah
Plus Salatigaserta MIM PK Kartasura dan MIM Karanganyar. Selanjutnya, inovasi dan transformasi manajemen, kurikulum dan program pendidikan pada tingkat SMP/MTs Muhammadiyah antara lain adalah SMP Muhammadiyah MBS Brebes, SMP Muhammadiyah PK Pracimantoro Wonogiri, dan SMP Muhammadiyah Al-Kausar Kartasura Sukoharjo. Adapun contoh inovasi dan transformasi manajemen, kurikulum dan program pendidikan pada tingkat SMA/ MA/SMK Muhammadiyah adalah SMA Muhammadiyah Dimsa Sragen dan SMK Muhammadiyah 1 Sukoharjo.

Salah satu bentuk inovasi dan transformasi kurikulum yang dilakukan oleh para pengelola sekolah Muhammadiyah di Jawa Tengah umumnya dimulai dari pengembangan Al-Islam dan Kemuhammadiyahan (AIK). Hal ini dilatarbelakangi oleh dua alasan pokok. Pertama, inovasi di bidang AIK akan berfungsi sebagai pemberi arah perubahan dan spirit bagi pengembangan sekolah Muhammadiyah pada bidang yang lain. Kedua, harus diakui bahwa inovasi di bidang AIK menjadi dimensi keunggulan yang layak "dijual" atau menjadi nilai tambah bagi sekolah-sekolah Muhammadiyah. Model pengembangan AIK yang selama ini dilakukan secara sporadis oleh para pengelola sekolahsekolah Muhammadiyah baik untuk satuan pendidikan pada tingkat SD/MI, SMP/MTs dan SMA/MA/SMK di Jawa Tengah difokuskan pada 2 komponen kurikulum, yaitu: komponen standar isi dan komponen standar proses.

Berdasarkan paparan di atas, penelitian ini memfokuskan kajiannya pada transformasi kurikulum AIK melalui dua komponen, yaitu: standar isi dan standar proses. Pemilihan dua standar ini berdasarkan alasan pokok bahwa kedua standar tersebut merupan dua komponen penting dalam kurikulum AIK. Selain itu, SMPM 01 Surakarta dan 
SMPM Plus Klaten yang dijadikan objek material dalam penelitian ini bersedia menyediakan data tentang dua standar tersebut secara memadai. Dengan demikian, dari kedua alasan tersebut penelitian ini membatasi kajiannya pada transformasi kurikulum AIK dengan focus pada standar isi dan standar proses.

Dari segi pendekatannya, penelitian ini merupakan gabungan dari dua pendekatan, yaitu: pendekatan penelitian kepustakaan (library research) dan pendekatan penelitian lapangan (field research). Penelitian kepustakaan digunakan untuk mengkaji teori kualitas sekolah dan transformasi kurikulum, sedangkan penelitian lapangan digunakan untuk mengkaji pengembangan kualitas sekolah Muhammadiyah dan mengkaji pengalaman sekolah Muhammadiyah dalam melakukan transformasikurikulum AIK. Adapun dari segi metodenya, penelitian ini menggunakan metode studi dokumen untuk menggali data tentang teori kualitas sekolah dan transformasi kurikulum dari berbagai buku dan jurnal ilmiah. Selanjutnya, penelitian ini juga menggunakan metode observasi dan wawancara, untuk menggali data tentang pengembangan kualitas sekolah Muhammadiyah dan pengalaman sekolah Muhammadiyah dalam melakukan transformasi kurikulum AIK.

\section{HASIL DAN PEMBAHASAN \\ Kualitas Sekolah dan Transformasi Kurikulum}

Isu tentang kualitas pertama-tama muncul di dunia industri dan utamanya pada industri jasa. Tren ini selanjutnya mempengaruhi layanan pendidikan, sehingga sekolah-sekolah di berbagai negara di dunia berlomba untuk menjadi sekolah yang berkualitas. Dalam beberapa referensi ditemukan penjelasan bahwa kualitas sekolah itu berarti kriteria yang dijadikan untuk mengukur kualitas sekolah berdasarkan pada tiga faktor esensial, yaitu: rasio guru dan peserta didik, jumlah peserta didik dalam kelas, serta pendidikan, pengalaman, dan pelatihan staf, baik guru maupun tenaga kependidikan (Endfield, 2007: 145-157). Berdasarkan tiga kriteria tersebut, sekolah yang berkualitas adalah sekolah yang memiliki rasio guru dan peserta didik 1:20, sekolah yang setiap kelasnya diikuti oleh 20 peserta didik.

Di pihak lain, Cynthia Guttman menyebutkan tiga indikator untuk mengukur kualitas tidaknya suatu sekolah. Ketiga indikator tersebuat adalah: guru, peserta didik, dan sarana belajar. Menurutnya, sekolah yang berkualitas adalah sekolah yang memiliki jumlah guru yang cukup, yang berwawasan luas, berketerampilan tinggi, dan bergaya interaktif dalam proses pembelajaran. Dari segi peserta didik, sekolah yang berkualitas adalah sekolah yang para peserta didiknya memiliki waktu yang cukup untuk belajar, memiliki budaya membaca yang kuat, dan menggunakan Bahasa nasional dalam proses pembelajaran. Adapun dari segi sarana belajarnya, sekolah yang berkualitas adalah sekolah yang didukung oleh kualitas materi ajar yang baik dan ketersediaan buku ajar yang cukup (Guttman, 2005; 42).

Berdasarkan kriteria dan indikatorindikator di atas, Cynthia Guttman menegaskan bahwa kualitas sekolah tidak bisa dicapai secara instan, melainkan melalui kerja keras dan proses yang panjang. Pertama-tama sekolah harus meningkatkan kompetensi dan profesionalisme para gurunya. Dari segi peserta didiknya, sekolah harus mengembangkan rasa ingin tahu yang tinggi dan budaya membaca di kalangan mereka. Faktor lainnya adalah sekolah harus menyiapkan kurikulum yang relevan dan menantang peserta didik untuk berkompetisi di tingkat global. Senada dengan Guttman, Marco 
Giannini menambahkan bahwa untuk mencapai sekolah yang berkualitas diperlukan beberapa tahapan yang jelas. Menurutnya, setidaknya ada 3 tahapan yang harus ditempuh oleh sekolah, yaitu: meningkatkan kompetensi guru melalui berbagai training dan pelatihan; memperkuat hubungan antara sekolah dan pengguna lulusan; serta mempromosikan model pembelajaran yang spesifik dengan kualitas materi ajar yang baik (Gianninia, 2015: 1735 - 1739). Yang menarik, baik Guttman maupun Giannini, mengakui bahwa kurikulum yang dimaknai sebagai materi ajar dalam proses pembelajaran dan buku ajar dijadikan rujukan oleh peserta didik selanjutnya dapat difungsikan sebagai salah satu sarana strategis untuk meningkatkan kualitas sekolah.

Sementara itu, istilah transformasi dalam beberapa referensi dimaknai sebagai "proses perubahan yang terjadi dalam berbagai aspek kehidupan manusia baik secara kuantitatif maupun kualitatif" (Fiels, 2013: 6-7). Makna ini bisa dihubungakan dengan perubahan hidup, perubahan masyarakat, perubahan kelembagaan, dan perubahan sekolah. Perubahan-perubahan tersebut oleh para ahli diyakini sebagai keniscayaan dalam kehidupan ini. Dalam konteks pendidikan, istilah transformasi oleh Manzoor Ahmed diletakkan sebagai output dari proses pendidikan. Baginya, pendidikan merupakan salah satu sarana strategis untuk melakukan transformasi pengetahuan,sikapdan perilakuseseorang atau sekelompok orang yang hidup di masyarakat atau negara tertentu (Ahmed, 2010: 511-517). Pada level yang lebih luas, pendidikan dapat memainkan peranan penting dalam mengubah masyarakat dan atau suatu negara sekalipun. Dengan kata lain, istilah transformasi dapat dipahami sebagai perubahan komponen pendidikan baik komponen kurikulum maupun semua komponen sekolah secara keseluruhan, dalam rangka mencapai tujuan pembelajaran (Arifin, 2011: 294).

Sebagai salah satu komponen pendidikan, kurikulum sekolah sering mengalami transformasi. Ketika masyarakat menghadapi problem penjajahan oleh negara lain, misalnya, kurikulum ditransformasi untuk membangun kesadaran dekoloniasai di kalangan para peserta didik di sekolah. Model transformasi kurikulum ini telah dilakukan oleh Kehdinga George Fomunyam \& Damtew Teferra (2017: 196207) di Afrika Selatan. Model transformasi kurikulum jenis ini juga pernah dilakukan oleh Giovanni Arduinia (2014: 2164-2168) di Italia, bahwa transformasi kurikulum difungsikan sebagai salah satu sarana strategis untuk mengembangkan masa depan dan keberlanjutan perguruan tinggi di Italia. Dalam konteks Indonesia, transformasi kurikulum Pendidikan Agama Islam ternyata berfungsi sebagai sarana penting untuk menanamkan nilainilai toleran dan kesadaran keadilan gender di kalangan peserta didik. Penelitian ini dilakukan oleh Husniyatus Salamah Zainiyati dan Nurwanto. Jika Zainiyati (2016: 285-308) memfokuskan penelitiannya pada kurikulum dan pemahaman Islam radikal, maka penelitian Nurwanto (2012: 149-173) memfokuskan penelitiannya pada buku teks dan keadilan gender.

Secara teoritik, transformasi kurikulum dapat dilakukan dengan model fungsional (functional models). Model ini diperkenalkan oleh Diane Browder, dkk. (2004: 211-223), peneliti di The University of North Carolina di Charlotte. Menurutnya, transformasi kurikulum model fungsional adalah proses memilih materi pembelajaran baik yang berupa konsep, sikap maupun keterampilan-keterampilan hidup seseorang atau sekelompok orang yang difungsikan sebagai sarana strategis untuk mengubah sekolah, lingkungan, 
dan peserta didik di masa yang akan datang. Model transformasi kurikulum ini oleh Browder digunakan untuk memberi akses pendidikan bagi peserta didik yang berada dalam kategori berkebutuhan khusus. Dalam hal ini, transformasi kurikulum memerlukan prioritas tertentu dan hanya terbatas pada peserta didik yang berkebutuhan khusus. Sebagai contoh, transformasi kurikulum model ini menjadikan keterampilan hidup yang diperlukan oleh kelompok peserta didik yang berkebutuhan khusus dijadikan materi pembelajaran baru dalam kurikulum. Di antara yang dibutuhkan oleh peserta didik adalah keterampilan hidup pada empat lingkungan, yaitu: komunitas, rekreasi, domestik, dan vokasional.

\section{Transformasi Kurikulum di Sekolah} Muhammadiyah

Dalam konteks Indonesia, salah satu komponen kurikulum yang penting adalahstandarisi. Adapun yang dimaksud dengan standar isi di sini adalah lingkup materi minimal dan tingkat kompetensi minimal untuk mencapai kompetensi lulusan minimal pada jenjang dan jenis pendidikan SMP (Permendikbud. nomor 20 tahun 2016). Pada bagian ini standar isi yang akan dideskripsikan adalah standar isi kurikulum Al-Islam dan Kemuhammadiyahan di dua sekolah Muhammadiyah, yaitu: Sekolah Menengah Pertama Muhammadiyah (SMPM) 01 Surakarta dan Sekolah Menengah Pertama Muhammadiyah (SMPM) Plus Klaten. Kedua sekolah ini dipilih dengan dua alasan pokok. Adapun alasan yang utama adalah bahwa kedua sekolah tersebut memiliki pengalaman penting dalam melakukan transformasi kurikulum AIK, terutama terkait dengan standar isi. Standar isi merupakan salah satu komponen inti dalam melakukan transformasi kurikulum dengan ketersediaan data yang memadai. Selain itu, kedua sekolah yang diteliti samasama menjamin ketersediaan data yang diperlukan dalam penelitian ini, terutama data terkait dengan model transformasi kurikulum AIK, khususnya komponen standar isi.

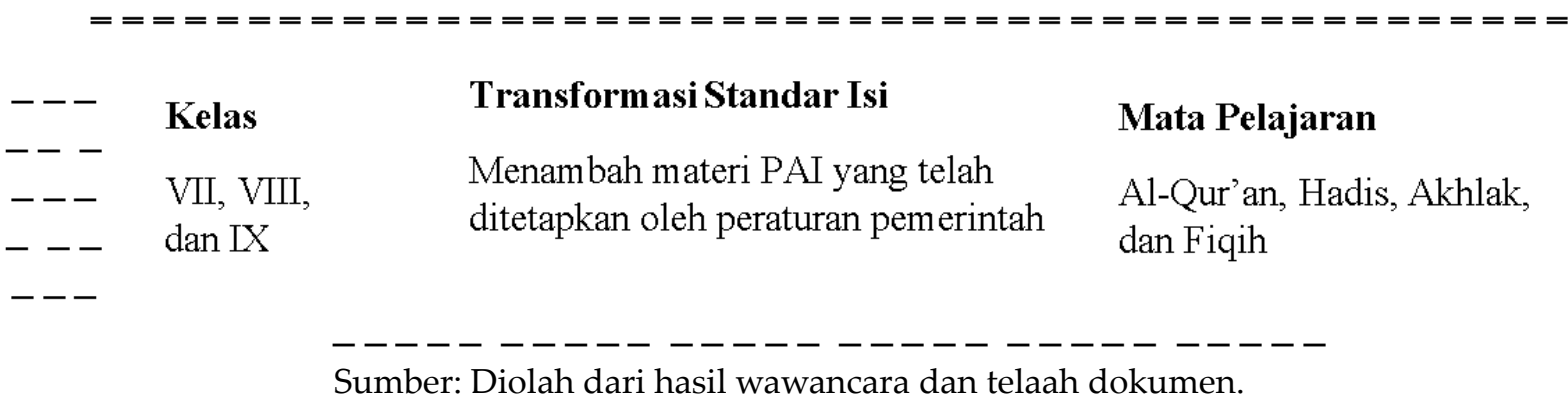

Gambar 1. Transformasi Standar Isi Kurikulum AIK di SMPM 01 Surakarta

Menurut kepala sekolah, standar isi kurikulum AIK yang ditetapkan oleh SMPM 01 Surakarta diakui telah dikembangkan dari dua peraturan pemerintah. Pertama, Keputusan Menteri Agama (KMA) No. 211 tahun 2011 tentang Standar Nasional Pendidikan Agama Islam. Kedua, Peraturan
Menteri Pendidikan dan Kebudayaan (Permendikbud) nomor 20, 21, 22, 23 tahun 2016 dan berdasarkan kompetensi inti dan kompetensi dasar yang diatur dalam Permendikbud nomor 24 tahun 2016. Gambar 1 menjelaskan bahwa model transformasi standar isi kurikulum AIK di SMPM 01 Surakarta ini dilakukan dengan 
cara menambah materi Pendidikan Agama Islam yang telah ditetapkan oleh peraturan pemerintah RI. Adapun penambahan materi tersebut selanjutnya ditempatkan pada 4 mata pelajaran, yaitu: Al-Qur'an, Hadis, Akhlak, dan Fiqih. Sementara dua mata pelajaran lainnya, yaitu: Akidah dan Tarikh/SKI tidak ada penambahan materi sama sekali.

Untuk mata pelajaran Al-Qur'an, ada penambahan materi berupa ayatayat pilihan seperti Q.S. Al-Baqarah: 255 (Ayat Kursi), Q.S. Al-Baqarah: 284-286 (Pujian Allah terhadap para Mukmin dan Do'a mereka), Q.S. Ali Imran: 2627 (Bukti-bukti Kekuasaan Allah SWT), Q.S. Al-Mukminun: 1-11 (Kemenangan Orang-orang Mukmin), Q.S. Al-Ahzab: 59 dan Q.S. An-Nur: 31 tentang (Menutup aurat bagi wanita). Sementara itu, untuk mata pelajaran Hadis, ada penambahan materi berupa hadis-hadis pilihan seperti hadis berbakti kepada orang tua; sholat berjamaah; menuntut ilmu; persaudaraan; ciri-ciri munafik; puasa; shadaqoh; beramal; pemimpin; menuntut ilmu sama dengan berjuang di jalan Allah; dua perkara yang menyelamatkan manusia; pahala amal yang tidak terputus; persaudaraan; kejujuran; dan malaikat mengepakkan sayapnya bagi penuntut ilmu.
Lebih lanjut, untuk mata pelajaran Akhlak ada penambahan materi berupa do'a-do'a pilihan seperti do'a keluar rumah; do'a penutup majlis; do'a setelah adzan; do'a naik kendaraan; do'a menjenguk orang sakit; do'a ketika memakai pakaian; do'a bercermin; do'a sebelum dan sesudah makan; do'a menjelang dan bangun tidur; do'a masuk kamar kecil; do'a keluar kamar kecil; do'a masuk masjid dan keluar masjid; do'a ketika turun hujan. Adapun untuk mata pelajaran Fiqih ada penambahan materi berupa cara berwudhu dan bertayamum, sholat dengan bacaan dan praktik mulai dari takbiratul ihram sampai salam sesuai dengan yang ditetapkan Majelis Tarjih Muhammadiyah; serta tata cara shalat jenazah.

Sementara itu, SMPM Plus Klaten melakukan transformasi standar isi kurikulum AIK dilakukan dengan cara menambahkan materi-materi Pendidikan Agama Islam yang telah ditetapkan oleh peratutan pemerintah, baik Kementerian Agama RI maupun Kementerian Pendidikan dan Kebudayaan RI. Penambahan materi tersebut diletakkan pada 6 mata pelajaran, yaitu: al-Qur'an dan Hadis, Aqidah, Ibadah, Akhlak, dan Tarikh/SKI, sebagaimana ditunjukkan pada gambar 2 .

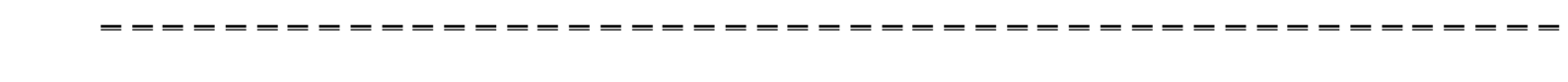 \\ Kelas $\quad$ Transformasi Standar Isi \\ $\begin{array}{lll}--- & \text { Menambah materi PAI yang telah }\end{array}$ \\ $\begin{array}{lll}--- & \text { dan IX } & \text { ditetapkan oleh peraturan pemerintah }\end{array}$ \\ Mata Pelajaran \\ Al-Qur'an, Hadis, Akidah, Ibadah, Akhlak, dan SKI \\ Sumber: Diolah dari hasil wawancara dan telaah dokumen.}

Gambar 2. Transformasi Standar Isi Kurikulum AIK di SMPM Plus Klaten

Adapun materi yang dipelajari kelas VII semester ganjil yaitu mata pelajaran (1) al-Qur'an tentang orangorang beriman, kafir, dan munafik (Q.S.
Al Baqarah: 1-20); (2) hadis tentang a. Islam, Iman, dan Ihsan; b. Balasan bagi amal orang mukmin dan kafir; c. Ciri-ciri orang Munafik; (3) aqidah tentang dinul 
Islam dan iman kepada Allah; (4) Akhlak tentang akhlakul karimah (siddīq, amānah, tablïgh, dan fathānah), dan akhläqul qobì ah; (5) Ibadah tentang thahärah, sholat fardhu, dan sholat berjama'ah; (6) Tarikh dan kebudayaan Islam tentang Masyarakat Arab Pra-Islam, Sejarah Nabi Muhammad SAW sampai diangkat menjadi Rasul, Dakwah Nabi Muhammad SAW; (7) Kemuhammadiyahan tentang pendidikan kemuhammadiyahan, berdirinya Muhammadiyah, Muhammadiyah dari sudut pandang ideologi, sejarah perumusan Matan Keyakinan dan CitaCita Hidup Muhammadiyah; serta (8) Bahasa Arab tentang Pelajaran 1, pelajaran 2, pelajaran 3, dan pelajaran 4 .

Materi kelas VIII semester ganjil yaitu mata pelajaran: (1) al Qur'an tentang orang Yahudi dalam Q.S. AlBaqarah: 83-101; (2) Hadis tentang iman; (3) Aqidah tentang iman kepada kitab Allah; (4) Akhlak tentang Sifat terpuji (ikhtiar dan tawakal) dan sifat tercela (anāniyah, namìmah, ghībah, gharab, dan rasad); (5) ibadah tentang puasa dan jual beli; (6) tarikh tentang sejarah khlulafāur rāsyidīn; (7) Kemuhammadiyahan tentang Muhammadiyah sebagai gerakan Islam dakwah amar ma'rüf nahi munkar, kepribadian dan perjuangan tokohtokoh Muhammadiyah, Amal Usaha Muhammadiyah; serta (8) Bahasa Arab tentang Pelajaran 1 Bepergian, pelajaran 2 Pergi ke Kantin, dan pelajaran 3 Nomor atau Angka.

Materi kelas IX semester ganjil yaitu mata pelajaran: (1) al-Qur'an tentang Q.S. At-Tin: 1-8, Q.S. Al-Alaq: 1-19, Q.S. Al-Baqarah: 153-157, Q.S. Al-Baqarah: 172-176, Q.S. Al-Baqarah: 183-86; (2) Hadis tentang hukum puasa ramadhan; (3) Aqidah tentang beriman kepada hari kiamat; (4) Akhlak tentang a. akhlak terpuji: qanā'ah, tasāmu -usnudzan;b. adab terhadap sesama makhluk hidup; (5) Ibadah tentang qurban dan aqiqah, haji dan umrah, perawatan jenazah; (6) Tarikh tentang sejarah perkembangan Islam di Nusantara; (7) Kemuhammadiyahan tentang pedoman hidup Islam Muhammadiyah, organisasi Muhammadiyah, organisasi otonom Muhammadiyah, janji pelajar Muhammadiyah; serta (8) Bahasa Arab tentang Perpustakaan dan Bermain Sepak Bola.

Model transformasi kurikulum AIK di SMPM Plus Klaten di atas sama persis denganmodeltransformasikurikulumAIK yang ditempuh oleh SMPM 01 Surakarta. Selain penambahan materi, transformasi kurikulum AIK juga dilakukan dengan cara penambahan 4 materi untuk kelas VII, yaitu: hafalan juz 30 dan 29, hafalan 30 hadis, pelaksanaan shalat berjamaah, dan kesediaan berdakwah di masyarakat sekitar. Adapun penambahan standar isi kurikulum AIK kelas VIII dilakukan dengan cara menambahkan 4 materi, yaitu: hafalan juz 30, 29, dan 1; hafalan 30 hadis; aturan Islam dalam berpuasa dan berjual-beli; serta dakwah lingkungan sekolah dan masyarakat. Selanjutnya, penambahan standar isi kurikulum AIK kelas IX dilakukan dengan menambahkan 4 materi, yaitu: hafalan juz 30, 29, dan 1; hafalan 30 hadis; tuntunan ibadah; dan dakwah di lingkungan sekolah dan masyarakat.

Memperhatikan uraian di atas dapat ditegaskan bahwa praktik transformasi kurikulum AIK di dua sekolah Muhammadiyah di atas telah mengonfirmasi hasil transformasi kurikulum yang dilakukan oleh Kehdinga George Fomunyam \& Damtew Teferra (2017: 196-207) di Afrika Selatan, dimana transformasi kurikulum berkontribusi dalam mengembangkan kesadaran peserta didik dalam melakukan upaya dekolonisasi di Afrika Selatan. Model transformasi kurikulum jenis ini juga pernah dilakukan oleh Giovanni Arduinia (2014: 2164-2168) di Italia, bahwa transformasi kurikulum berperan 
penting dalam pengembangan masa depan dan keberlanjutan perguruan tinggi di Italia. Lebih lanjut, praktik transformasi kurikulum AIK di dua sekolah Muhammadiyah di atas telah memperkuat hasil penelitian yang dilakukan oleh Husniyatus Salamah Zainiyati dan Nurwanto di Indonesia. Hasil kedua penelitian tersebut disamping memperkuat hasil penelitian para peneliti di Afrika Selatan dan Italia, juga berimplikasi pada peran penting transformasi kurikulum AIK dalam pengembangan kualitas sekolah di SMPM 01 Surakarta dan SMPM Plus Klaten.

Jika dilihat dari modelnya, transformasi standar isi pada kurikulum AIK di dua sekolah Muhammadiyah di atas menunjukkan bahwa baik SMPM 01 Surakarta maupun SMPM Plus Klaten telah memilih model fungsional dalam kegiatan transformasi kurikulum AIK. Model ini dipilih dengan alasan bahwa kegiatan transformasi kurikulum AIK difungsikan untuk mengembangkan sekolahMuhammadiyahyangberkualitas, dengan ciri khusus pada pengembangan komponen utama dalam kurikulum AIK, yaitu transformasi pada standar isi. Pemilihan model ini sangat tepat jika dilihat dari teori yang ditawarkan oleh Diane Browder, dkk., peneliti di The University of North Carolina di Charlotte.

\section{Kualitas Sekolah Muhammadiyah}

Pada bagian sebelumnya telah dijelaskan bahwa salah satu indikator penting dari kualitas sekolah adalah ketersediaan guru yang cukup, berwawasan luas, berpendidikan tinggi, ahli dan terampil dalam mengelola proses pembelajaran yang aktif dan interaktif. Dalam arti ini, dua sekolah Muhammadiyah yang diteliti, yaitu: SMPM 01 Surakarta dan SMPM Plus Klaten telah memenuhi syarat untuk dimasukkan dalam kategori sekolah Muhammadiyah yang berkualitas. Pada bagian ini, data yang digunakan untuk membangun argumen bahwa kedua sekolah Muhammadiyah tersebut di atas masuk dalam kategori sekolah berkualitas adalah standar proses yang dikembangkan oleh kedua sekolah. Adapun yang dimaksud dengan standar proses di sini adalah pedoman, atau tahapan langkah-langkah bagi para guru saat mereka memberikan pembelajaran dalam kelas, dengan harapan proses pendidikan yang berlangsung bisa efektif, efesien dan inovatif; sehingga beberapa target atau kriteria mengenai komptensi lulusan dapat tercapai dengan sempurna (PP RI No. 32 Tahun 2013 tentang Perubahan SNP).

Terkait dengan standar proses, SMPM 01 Surakarta telah melakukan transformasi standar proses pada kurikulum AIK dengan cara menambah kegiatan ko-kurikuler dan ekstrakurikuler keagamaan. Kedua kegiatan tersebut bertujuan agar membentuk kepribadian peserta didik yang sesuai dengan apa yang diajarkan al-Qur'an dan yang dicontohkan oleh Rasulullah SAW. Adapun yang termasuk kegiatan ko-kurikuler keagamaan adalah pembentukan kelompok untuk kelas Program Khusus daninfaq setiap hari yang nantinya akan disalurkan kepada yang berhak menerima, termasuk peserta didik yang kurang mampu serta peserta didik atau warga sekolah yang sedang sakit. Sementara itu, yang termasuk kegiatan ekstra-kurikuler keagamaan adalah tadarus pagi, shalat berjama'ah, latihan membaca iqro', al-Qur'an, dan tahfidz, serta kegiatan keputrian, sebagaimana yang ditunjukkan oleh gambar 3. Kedua kegiatan tersebut diberlakukan pada semua kelas, yaitu: kelas VII, VIII, dan IX. 
Transformasi Standar Proses

Menambah dua kegiatan, yaitu: kegiatan ko-kurikuler dan ekstrakurikuler

\section{Bentuk Kegiatan}

Pembentukan program khusus, infaq, tadarus pagi, adzan, shalat berjamaah, shalat Sunnah rawatib, dzikir, do'a, iqra', alQur'an, tahfidz, dan keputrian
Metode

Pembiasaan, praktik, hafalan, serta latihan dan pengulangan

Sumber: Diolah dari hasil wawancara dan telaah dokumen.

Gambar 3. Transformasi Standar Proses Kurikulum AIK di SMPM 01 Surakarta

\section{Transformasi Standar} Proses

Memperkuat mata pelajaran wajib serta menambah kegiatan kokurikuler dan ekstra-kurikuler

\section{Bentuk Kegiatan}

Penguatan kegiatan formal, kegiatan mentoring dan kajian keislaman, hafalan al-Qur'an, praktik dakwah, shalat dhuha, dan shalat berjama'ah

\section{Metode}

Tanya jawab, diskusi, game, hafalan, latihan dan praktik, dan pembiasaan

Sumber: Diolah dari hasil wawancara dan telaah dokumen.

\section{Gambar 4. Transformasi Standar Proses Kurikulum AIK di SMPM Plus Klaten}

Dilihat dari prosesnya, kegiatan kokurikulerdanekstra-kurikuler keagamaan di atas dilakukan dengan metode yang bervariasi. Metode yang dimaksud adalah metode pembiasaan, praktik, hafalan, serta latihan dan pengulangan. Metode pembiasaan digunakan dalam kegiatan tadarus pagi sebelum pembelajaran intrakurikuler dan shalat berjamaah, terutama shalat dhuhur dan asar; shalat sunnah rawatib, dan berdzikir setelah shalat berjama'ah. Metode praktik digunakan dalam kegiatan adzan, praktik menjadi imam shalat, dan praktik menulis arab berbasis al-Qur'an dengan model khat indah. Selanjutnya, metode hafalan digunakan dalam kegiatan hafalan do'a harian dan tahfidz. Metode latihan dan pengulangan digunakan dalam kegiatan membaca iqra', al-Qur'an, dan tahfidz terutama dari segi tajwid dan tahsinnya.

Di pihak lain, SMPM Plus Klaten telah melakukan transformasi standar proses pada kurikulum AIK dengan cara memperkuat standar proses melalui dua cara. Pertama, penguatan melalui mata pelajaran wajib yang telah ditetapkan oleh Majelis Pendidikan Dasar dan Menengah Pimpinan Pusat Muhammadiyah. Mata pelajaran wajib yang dimaksud adalah mata pelajaran Al-Qur'an dan Hadis, Aqidah, Ibadah, Akhlak, dan Tarikh atau SKI, dilaksanakan dalam kegiatan formal di dalam kelas dalam waktu rata-rata 1x40 menit. Kedua, penguatan melalui kegiatan ko-kurikuler dan ekstrakurikuler keagamaan. Yang termasuk ke dalamnya adalah: kegiatan mentoring dan kajian keislaman, hafalan al-Qur'an, praktik dakwah, sholat dhuha, dan shalat dhuhur dan ashar berjama'ah. Kegiatan tersebut dilaksanakan bersifat wajib dan rutin untuk semua kelas, yaitu: kelas VII, VIII, dan kelas IX sesuai jadwal mata pelajaran, sebagaimana tergambar pada gambar 4.

Proses kegiatan-kegiatan di atas disampaikan oleh para guru dengan menggunakan metode yang bervariasi. Metode yang dimaksud adalah metode 
tanya jawab, diskusi, game, hafalan, latihan dan praktik, serta pembiasaan. Metode tanya jawab, diskusi dan game digunakan dalam kegiatan mata pelajaran Al-Qur'an dan Hadis, Aqidah, Ibadah, Akhlak, dan Tarikh atau SKI yang dilaksanakan dalam kegiatan formal di dalam kelas dalam waktu rata-rata $1 \times 40$ menit. Selain itu, ketiga jenis metode tersebut juga digunakan dalam kegiatan mentoring dan kajian keislaman. Selanjutnya, metode hafalan, latihan dan praktik digunakan dalam kegiatan baca al-Qur'an dan hafalan dengan penekanan pada tajwid dan tahsinnya; kegiatan dakwah baik da'i untuk peserta didik laki-laki maupun da'iyah untuk peserta didik perempuan. Adapun metode pembiasaan digunakan dalam kegiatan shalat dhuha dan shalat berjama'ah, terutama shalat dhuhur dan asar.

Berdasarkan deskripsi pengalaman dua sekolah Muhammadiyah dalam melakukan transformasi standar proses pada kurikulum AIK di atas menunjukkan bahwa praktik transformasi kurikulum AIK diakui mempermudah kepala sekolah dan para gurunya untuk mengembangkan sekolah Muhammadiyah yang berkualitas. Kemudahan ini didukung oleh ketersediaan guru yang cukup, berwawasan luas, berpendidikan tinggi, ahli dan terampil dalam mengelola proses pembelajaran yang aktif dan interaktif. Model pembelajaran aktif dan partisipatif ini digunakan secara konsisten oleh para guru di dua sekolah Muhammadiyah, baik dalam kegiatan proses pembelajaran di dalam kelas maupun dalam kegiatan ko-kurikuler dan ekstra-kurikuler keagamaan. Penggunaan model pembelajaran aktif teramati dari kegiatan hafalan al-Qur'an, praktik dakwah, shalat dhuha, dan shalat berjama'ah. Sementara itu, model pembelajaran partisipatif teramati dari kegiatan proses belajar mengajar di dalam kelas, kegiatan mentoring dan kajian keislaman.
Jika dilihat dari indikator sekolah berkualitas, transformasi standar proses pada kurikulum AIK di dua sekolah Muhammadiyah di atas menunjukkan bahwa baik SMPM 01 Surakarta maupun SMPM Plus Klaten telah memenuhi salah satu kriteria dan indikator utama tentang sekolah berkualitas, terutama terkait dengan kompetensi guru sebagai pelaksana kurikulum di sekolah. Kriteria dan indikator ini dipilih dengan alasan bahwa kegiatan transformasi kurikulum AIK difungsikan untuk mengembangkan sekolahMuhammadiyahyang berkualitas, dengan ciri khusus pada kompetensi guru yang berwawasan luas, terlatih, dan terampil dalam mengimplementasikan kurikulum AIK melalui pengembangan standar proses pembelajaran. Pemilihan kriteria dan indikator ini sangat tepat jika dilihat dari teori yang ditawarkan oleh Claude S. Endfield dan Cynthia Guttman.

\section{PENUTUP}

Upaya mengembangkan sekolah Muhammadiyah berkualitas oleh SMPM 01 Surakarta dan SMPM Plus Klaten dilakukan dengan cara transformasi kurikulum AIK. Cara ini difokuskan pada pengembangan dua standar, yaitu: standar isi dan standar proses. Dalam konteks standar isi, kedua sekolah melakukan pengembangan standar isi dengan cara menambah materi Pendidikan Agama Islam yang telah ditetapkan oleh peraturan pemerintah, baik Keputusan Menteri Agama (KMA) No. 211 tahun 2011 tentang Standar Nasional Pendidikan Agama Islam maupun Peraturan Menteri Pendidikan dan Kebudayaan (Permendikbud) nomor 20, 21, 22, 23 tahun 2016 dan berdasarkan kompetensi inti dan kompetensi dasar yang diatur dalam Permendikbud nomor 24 tahun 2016. Penambahan materi tersebut diletakkan pada mata pelajaran al-Qur'an, Hadis, Akidah, Akhlak, dan SKI. Penambahan ini diberlakukan untuk 
kelas VII, VIII, dan IX. Jika dilihat dari perspektif teoritik, praktik transformasi kurikulum AIK ini menggunakan model fungsional. Pemilihan model transformasi seperti ini sangat tepat dengan alasan bahwa model fungsional ini sangat praktis difungsikan untuk mengembangkan sekolahMuhammadiyah yang berkualitas.

Proses pembelajaran AIK sangat potensial untuk mengembangkan sekolah Muhammadiyah berkualitas. Hal ini dibuktikan oleh kedua sekolah, bahwa pengembangan standar proses dijadikan salah satu fokus dalam pelaksanaan transformasi kurikulum AIK. Konsekuensi logis dari pelaksanaan transformasi kurikulum AIK ini berdampak pada peningkatan kualiatas sekolah Muhammadiyah, yang pada akhirnya berdampak positif pada peningkatan animo masyarakat untuk menyekolahkan putera-puterinya di sekolah Muhammadiyah. Adapun bentuk transformasi kurikulum AIK di dua sekolah yang diteliti adalah mengembangkan standar proses kurikulum AIK dengan cara menambah dua kegiatan, yaitu: kegiatan kokurikuler dan ekstra-kurikuler keagamaan. Khusus untuk SMPM Plus
Klaten juga memperkuat kegiatan proses pembelajaran di kelas. Penamabahan dan penguatan tersebut diberlakukan untuk semua kelas, yaitu: kelas VII, VIII, dan IX. Jika dilihat dari perspektif teoritik, praktik transformasi kurikulum AIK ini menggunakan kriteria dan indikator kompetensi guru, terutama yang terkait dengan ketersediaan guru yang cukup, berwawasan luas, berpendidikan tinggi, terlatih, dan terampil dalam mengelola proses pembelajaran AIK. Selanjutnya, jika dilihat dari metode pembelajarannya, para guru menggunakan metode pembelajaran yang bervariasi, yaitu: pembiasaan, hafalan, latihan dan pengulangan, tanya jawab, diskusi, game, dan praktik.

Selanjutnya, kepada para peneliti direkomendasikan untuk melanjutkan penelitian ini dengan fokus pada sekolah Muhammadiyah level Sekolah Menengah Atas dan atau Sekolah Menengah Kejuruan. Rekomendasi ini diberikan mengingat penelitian ini hanya membatasi konteksnya pada sekolah Muhammadiyah level Sekolah Menengah Pertama yang berlokasi di Surakarta dan Klaten.

\section{DAFTAR PUSTAKA}

Ahmed, Manzoor, "Education as Transformation - Education for transformatif", Society for International Development, 2010, 53(4), 511-517.

Ali, Mohama, "Membedah Tujuan Pendidikan Muhammadiyah", Profetika, Jurnal Studi Islam, Vol. 17, No. 1, Juni 2016: 43-56.

Arduinia, Giovanni, "The relationship between comprehensive school, the principle of educational continuity and the research on vertical curriculum", Social and Behavioral Sciences, 116 (2014), 2164 - 2168.

Arifin, Zaenal, Konsep dan Model Pengembangan Kurikulum, (Bandung: PT, Remaja Rosdakarya, 2011), hlm. 294.

Browder,Diane, at.all., "TheAlignmentofAlternativeAssessmentContentwithAcademic and Functional Curricula", The Journal of Special Education, Vol. 37, Iss. 4, (Winter 2004): 211-223.

COLLIN, ELIZABETH FULlER, “ISLAM AND THE HABITS OF 
DEMOCRACY: ISLAMIC ORGANIZATIONS IN POST-NEW ORDER SOUTH SUMATRA", INDONESIA ITHACA, ISS. 78, (OCT 2004): 93-120.

Daftar Lembaga Pendidikan Muhammadiyah Jawa Tengah pada Tahun 2016.

ENDFIELD, CLAUDE S. “DEFINING QUALITY: NEW INSIGHTS FOR TRAINING PRACTITIONERS", CANADIAN JOURNAL OF NATIVE EDUCATION; EDMONTON VOL. 30, ISS. 1, (2007): 145-157,189.

Fiels, Keith Michael, "Defining Transformation", American Library Magazine, Vol. 44, Iss. 5, (May 2013), 6-7.

Fomunyam, Kehdinga George \& Damtew Teferra, “Curriculum responsiveness within the context of decolonisation in South African higher Education", Perspectives in Education, 2017 35(2), 196-207.

Gianninia, Marco, "Organization and quality in school education”, Social and Behavioral Sciences 174 (2015), $1735-1739$.

Guttman, Cyntia, "Defining Quality and Inequality in Education”, UN Chronicle; MarMay 2005; 42, 1; Research Library pg. 49.

Husin, Asna, "Educating For Islamic Pluralism: Lessons From Indonesia", Islam and Civilisational Renewal, Kuala Lumpur Vol. 1, Iss. 1, (Oct 2009): 121-141.

Laporan Majelis Dikdasmen PPM Periode 2010-2015, 2015, 198.

Majelis Dikdasmen, 2015. “Laporan Pelaksanaan Program dan Kegiatan Majelis Pendidikan Dasar dan Menengah Pimpinan Pusat Muhammadiyah Periode 2010-2015", hlm. 197-211, dalam Pimpinan Pusat Muhammadiyah, 2015. Laporan Majelis Pimpinan Pusat Muhammadiyah Periode 2010-2015, disampaikan pada Muktamar Muhammadiyah ke-47, Makassar 18-22 Syawal 1436 H/3-7 Agustus 2015.

Nurwanto, "The portrait of gender justice and injustice in the Islamic teaching textbook and Muhammadiyah teachers' responses", Indonesian Journal of Islam and Muslim Societies, Volume 3, Number 1, June 2012: 149-173.

Pendidikan Dasar dan Menengah Pimpinan Pusat Muhammadiyah, Bab III Standart Isi, hlm. 12-35.

Peraturan Menteri Pendidikan dan Kebudayaan (Permendikbud) nomor 20 tahun 2016 tentang Standar Isi. Lihat juga, Keputusan Menteri Agama (KMA) No. 211 tahun 2011 tentang Standar Nasional Pendidikan Agama Islam.

Perturan Pemerintah Republik Indonesia No. 32 Tahun 2013 tentang Perubahan Standar Nasional Pendidikan.

Tim Penyusun, Al Islam dan Kemuhammadiyahan untuk SMP/MTs Muhammadiyah, (Surakarta: Majelis Pendidikan Dasar dan Menengah Pimpinan Daerah Muhammadiyah Kota Surakarta, tanpa tahun), tanpa halaman.

Zainiyati, Husniyatus Salamah, "Curriculum, Islamic Understanding And Radical Islamic Movements In Indonesia", Journal of Islam Indonesia, Volume 10, Number 02, (December 2016), 285 - 308. 